\title{
Erratum to: Primary vs. delayed perineal proctectomy-there is no free lunch
}

\author{
Vitaliy Poylin $^{1} \cdot$ Thomas Curran $^{1} \cdot$ Daniel Alvarez $^{1} \cdot$ Deborah Nagle $^{1}$. \\ Thomas Cataldo ${ }^{1}$
}

Published online: 24 May 2017

(C) Springer-Verlag Berlin Heidelberg 2017

Erratum to: Int J Colorectal Dis

DOI 10.1007/s00384-017-2790-z

The article was originally published with missing authors.

All author names have now been added and appear correctly above. The original article was corrected.

The online version of the original article can be found at doi: http://dx.doi. org/10.1007/s00384-017-2790-z

\footnotetext{
Vitaliy Poylin

vpoylin@bidmc.harvard.edu
}

1 Department of Surgery, Division of Colon and Rectal Surgery, Beth Israel Deaconess Medical Center, Harvard Medical School,

Boston, MA, USA 